\title{
From Foreign Migration to Cultural Affinity: The Journey of Foreign Expatriates toward Filipino Cultural Adaptation
}

\author{
Danilo Keh Jr. MAED., Castillo Hans Rainer C., Sali, Marwa S., Rodriguez Maria Kristina, Uy \\ Luis Miguel S.
}

\begin{abstract}
Background. The present study puts forward a discourse on the journey of non-Filipino expatriates in Qatar who are deeply immersed in the Filipino culture. Its main focus is to extrapolate their experiences regarding living and working with Filipinos; paving the way for their eventual adaptation of Filipino values and practices; hence, cultural affiliation. Method. A phenomenological research design was utilized to understand the lived experiences and perceptions of the Filipinized expatriates, focusing on the central question: "How do the foreign expatriates adapt to the Filipino culture?" A semi-structured interview was conducted to gather data. The data gathered were analysed using an inductive approach in theme development. Findings: The findings extrapolate the degree of influence the Filipino culture has on these foreign expatriates. It underscores three themes from the respondents' verbalization of their experiences namely: Filipino Values, Customs and Traditions, and Acculturation. Conclusion. The Filipino culture is permeating. It has enriched the lives of non-Filipinos and has made them appreciate and lived the Filipino way of life. Hence, non-Filipinos showcase different adaptation skills in order to make sense of the foreign culture they are immersed in.
\end{abstract}

Recommendation. The paper suggests that future researchers consider a more diverse selection of nationalities.

Index Terms - Cultural Affinity, Adaptation, Filipino Culture, non-Filipino Expatriates, Acculturation.

\section{INTRODUCTION}

Qatar is one of the booming work destinations of OFWs. This progressive Middle Eastern country has become the second home of many skilled and professional workers in search of a better life. In fact, the Filipino community is one of Qatar's fastest growing foreign communities, second only to Bangladesh (P. Souza, 2017). Also, according to a 2017 population report (P. Souza, 2017) there are as many as 260,000 Filipinos living in Qatar as of January 2017, making it the fourth biggest group of foreign workers in Qatar. The surge in numbers can be attributed to the rising demand for Filipino workers in the fields of construction as the Arab country builds infrastructure in preparation for its hosting of the 2022 FIFA World Cup (Hapal, 2017).

Danilo Keh Jr. MAED. ${ }_{1,2,3}$,Castillo, Hans Rainer C.1,2,3, Sali

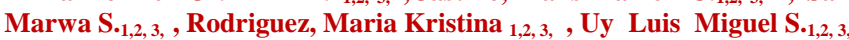
1. Philippine School Doha, Doha, Qatar

2. Research Development, Accreditation and Publication Office, PSD, Doha, Qatar

3. Research Capstone Project, PSD, Doha, Qatar
The country has successfully created a name for itself in the world market. Its economy heavily relies on migrant labor, resulting to a high number of expatriates that outnumbers its natives (Hapal, 2017). It has built its legacy embracing plurality of contexts. As foreign expatriates settle in this country, they bring with them their own contexts facilitating cultural exchange. Hence, the country becomes a melting pot of cultures; a fusion of different ways of life.

With globalization as the trend of the world, more and more people are acknowledging and are living witnesses of the multiplicity of interpreting existential realities. As borders between and among countries vanish dramatically, the process of cultural exchange become more fluid than ever before. As Filipinos go across the world to find work and socialize, they leave behind their own cultural footprint, influencing others in return.

In a way, Overseas Filipino Workers (OFWs) are modern-day heroes. Not only do they carry on their backs the country's economy, they are the concrete embodiment of hard work, sacrifice, and dedication. Without exaggeration, they are known throughout the world not only because of their skills, but the love they show towards their work. They are the primary vehicles of the Filipino culture per se in the global arena; making their way of life known across continents.

The present study primarily focuses on the lived experiences of non-Filipinos as they live and work with Filipino nationals. The aim is to unravel the adaptation skills that these foreign expatriates undergo through prompted by their long and constant immersion to the Filipino Culture. As the Filipino culture is alive and vibrant, so its influences permeate the lives of non-Filipino expatriates.

The study unravels the foreign nationals' journey towards cultural affinity. As countless immigrants, refugees, and temporary sojourners, as well as domestic migrants, leave the familiar surroundings of their home culture and resettle in a new cultural environment for varying lengths of time, they find themselves in need of establishing and maintaining a relatively stable working relationship with the host environment (Kim, 2017). Through the process of acculturation, foreign expatriates learn to make adjustments in their own cultural habits and are able to achieve a level of effectiveness in the new setting. This process takes place through communication and interaction between the individual and the people he or she is surrounded with. 


\section{From Foreign Migration to Cultural Affinity: The Journey of Foreign Expatriates toward Filipino Cultural Adaptation}

Cultural affinity is a process of cultural and psychological change that results from the continuing contact between people of different cultural backgrounds (Berry, 2006). Through continuous interaction, foreign expatriates of different cultures have adapted to different traits of another culture which results to development of more than one cultural and linguistic entity existing in them. Although, living in a country that has a different cultural background from one's own is a challenging process, it is common for every foreign expatriate to experience this.

Foreigners are attracted to Filipinos because they are extremely talented at showing a positive and strong commitment face that foreigners appreciate (DeGreg, 2018). In addition, their benevolent hospitality has reached the heart of foreigners which then received much praise. These are merely a portion of the vast characteristics that Filipinos are known for which left an impact on not only the foreigners but also on the world as people know it.

Based on the verbal musings of the non-Filipino respondents and with the validation of related researches,

\section{METHOD}

The method of gathering the required data was accomplished through interviews. Developmental questions that relate to the central question "How do the foreign expats adapt to the Filipino culture?" were created to ensure that the cultural adaptation skills of non-Filipinos will come to light. These questions were analyzed and clustered to produce the recurring themes and the aforementioned simulacrum. The by-product, then, of the respondents' verbalization of their lived experiences extrapolates their journey from foreign migration to Filipino cultural affinity.

The research flow is empirically observed using the following steps in data analysis: (1) transcription of data; (2) Emic to Etic transcription; (3) cool to warm analysis; (4) identifying and analyzing themes; (5) and creation of the simulacrum.

\section{Study Design}

The study consists of a phenomenological design. This type of design attempts to explore personal experience and is concerned with the respondent's personal perception or experience of a certain object or event (Smith, J.A. \& Osborn, M., 2004). The focus of this study are the experiences of the Filipinized expatriates. The aim is to determine the recurring themes that stem from the semi-structured interview.

\section{Research Locus and Sample}

The respondents were foreign expats who were very well familiar with the Filipino culture. Purposive sampling was utilized in this study. This is a type of non-probability sampling that is most effective when the authors need to study a certain cultural domain with knowledgeable respondents with experience regarding the topic (Tongco, $\mathrm{M}$. D. C., 2007). A total of six $(n=6)$ foreign expats were chosen for the semi-structured interview conducted. The researchers made sure that the interview was professionally done. A clear set of criteria (foreign national, working adult, long and constant exposure to the Filipino culture such as having a spouse who is Filipino, living in an accommodation with a Filipino, and/or working with Filipinos for at least three years) was utilized to ensure that the selected respondents were qualified to unravel the phenomenon being explored.

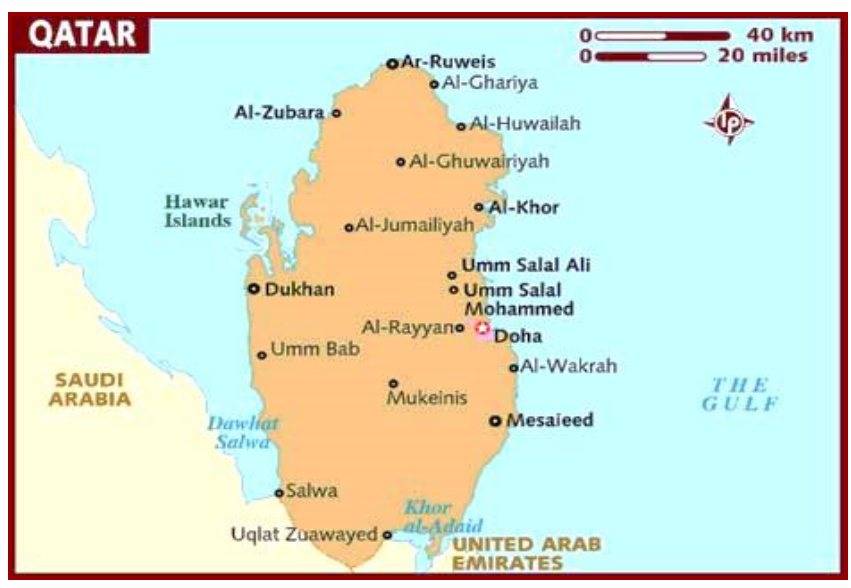

Figure 1 Map of Qatar

\section{Data Collection and Ethical Consideration}

Data were collected through a semi-structured interview. The questionnaire was validated by several teachers to ensure that the questions will readily address the topic at hand. Data collection started by writing a letter to the proposed respondents which explains in detail the study to be conducted. Following the respondents' acceptance, the time and place for the interview were set. The interview gave the participants the avenue to share their understanding of the specific phenomenon being explored. Data were recorded by hand and recorded using a cellphone. To maintain confidentiality, the names of the respondents were referred to as $\mathrm{P} 1, \mathrm{P} 2$, and so on

\section{FINDINGS}

Qatar is one of the countries in the Middle East with the highest concentration of OFWs. Due to the lucrative wages and benefits being offered, the country has seen an increase in the number of Filipino expatriates over the course of many years. Quoting figures provided by the Ministry of Interior, the ministry said the number of Filipinos now working in the country was 222,712, while the number for 2015 was 188,000. The Philippine Overseas Labor Office (POLO) in Doha expects to see a continuing demand for almost all categories of Filipino workers, including skilled, semi-skilled, low-skilled, household service workers, and professionals (Aguilar, 2016).

The influx of Filipinos in Qatar allows for frequent interactions with the other foreign expatriates, resulting in cultural exchange and acculturation. In this regard, the study 


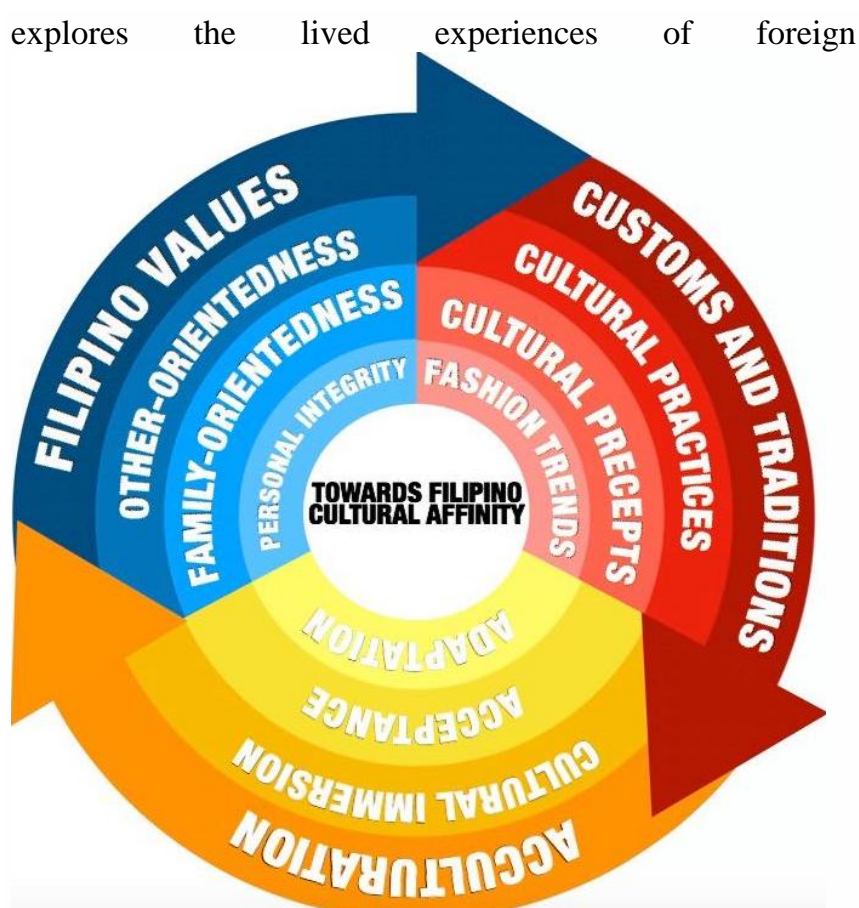

Figure 2 Simulacrum Factors that Affect the Foreign Expatriates

nationalities who came into close contact with Filipinos either professionally or personally. It tries to address the process of cultural expansion and evaluate how foreign nationalities have integrated the Filipino culture in their own belief system and how they became more Filipino. The goal of the study is to examine their interactions with Filipinos which resulted to a change in their cultural presumptions inducing cultural fusion.

In this regard, Filipino culture is constantly being transmitted consciously or unconsciously. This is the reason why this phenomenological study centers on the impact of the Filipinos' way of life to the foreign nationals that they encounter. Through the verbal musings of the respondents and the verbalizations of their ideas, three themes were created. These are (1) Filipino Values, which include other-orientedness, family-orientedness, and personal integrity; (2) Customs and Traditions, which include cultural practices, cultural precepts and fashion-trends and; (3) Acculturation, which include cultural immersion, acceptance, and adaptation.

\section{Filipino Values}

Filipino values are highly respected by foreign nationals. These values help them to better understand who Filipinos are and the things they give importance to. Not only are these values given high regard, foreigners are willing to learn and apply these in daily life. Without a doubt, they were able to imbibe the Filipino value system.

Since values lie at the heart of the culture, they reveal who Filipinos are; their aspirations, dreams and the things they believe in. Not only are these values self-identifying, they represent what Filipinos consider true, good, and beautiful. These values are undoubtedly transferable and alluring. Foreigners, as a consequence, have found themselves practicing them.
The Filipinos are well-known for being hospitable. They are other-oriented so to speak. Welcoming guests with much gusto has always been one of their most defining traits. They are renowned worldwide for treating their guests warmly, whether natives or foreigners. The Filipino hospitality is something to take pride in (Thomas, 2016). As the respondents mentioned:

"The thing I respect the most among Filipinos is how they helped me while I was studying in the Philippines. They are very open with me and try to support me until I finish my task." (P1)

\begin{abstract}
"One value that was greatly appreciated was the warmth that Filipinos exhibit when it comes to greeting; making them approachable even more so than other nationalities. (P5)",

"The liveliness of the Filipinos, they entertain and make sure you are well looked after, and they try to make the best out of life." (P2)
\end{abstract}

\section{"The things I like about Filipinos are friendliness, willingness, and that they would do everything for each other." (P6)}

Filipinos are known to be friendly and hospitable. They show support when they help someone without expecting something in return. The Filipino helping hand knows no culture, race, and religion. The joy and fulfilment they feel are enough in exchange for the help they gave. These positive actions shown by Filipinos made a lasting impression on the foreign expats. Being surrounded by the Filipinos allows these individuals to learn and appreciate the friendliness and hospitality of the Filipinos.

Filipino hospitality is compassion-centered. They care for others and treat them with utmost respect. They treat everyone as part of the family. They make people around them feel loved. Empathy is one of the most prized values of Filipinos.

In addition to other-orientedness, Filipinos value their families as they treat them with the greatest reverence. One can say that Filipinos are Filipinos for the tremendous love and dedication they show to the family. In a nutshell, they prioritize their family before anything else. As the following responses mentioned:

"The Filipino culture that is worth emulating is being together with all of your family members. Make time for your family. Don't get caught up in work and be too busy to visit or call. Just stay together because when you get to work, life's going to get busy and you will sometimes feel sad that you miss the holiday and be with your family. The things that is really worth emulating about the Filipinos are making the effort to be together as a family." (P6) 
"The family values and generosity of Filipinos are the things I look up to." (P2) "I am comfortable as the culture is aligned with my principles, the prospect of family values and respect are present." (P2)

"Yes, as what I've explained in the last five questions, Filipinos share happiness, they put pride in their work, and they treat everyone as their family. They strengthen family values." (P6)

"There is similarity in terms of being generous. Filipinos help relatives but at a greater degree compared to Sri Lankans. They generally have a higher range in terms of family, usually helping even those in the extended part of the family. Sri Lankans usually only help relatives from the immediate family. " (P2)

"I would choose the Filipino culture because it's somehow related to the Malaysian culture. There are close family ties with Filipino culture, as the children grow as long as the parents can support them regardless of having a job or not the children are still allowed to stay in their parents' house. Unlike other foreign countries children are already kicked out upon reaching the legal age." (P5)

Moreover, Filipinos uphold personal integrity. They are naturally born to be honest and raised by their parents with the virtue of honesty as their guiding principle in life (Apolinar, n.d.). As the respondents mentioned,

\begin{abstract}
"They value honesty; therefore, they do not cheat." (P4)

"The Filipinos at work are honest and independent. This is what something a Nepali like me should learn." (P4)

"I prefer to accept the Filipino culture because it is the most impressive culture for me. They are very fascinating in terms of their fashion, cleanliness, maturity, honesty and punctuality." (P4)
\end{abstract}

Foreigners adore Filipinos for being honest. They maintain personal integrity in all undertaking. Not only are they honest professionally and personally, they are faithful to their responsibilities and tasks. They are hardworking and they take pride in doing their work. Foreign expats who work with Filipinos appreciate how integrity has been ingrained in the Filipino psyche. Eventually, foreign expats have found themselves adapting Filipino values.

"I learned how respectful Filipinos are and how innovative they are. They are especially hardworking and professional that I base my experiences from them." (P4)
"They show it by working together and helping. They are able to do what needs to be done." (P1)

Filipino values are truly influential. Other-orientedness, family-orientedness, and personal integrity are some of the traits Filipinos have that make foreigners appreciate them more. More so, through these values, these expats become more Filipinos in their actions and words.

\section{Customs and Traditions}

An essential part of the Filipino culture which the expatriates have slowly come to accept is its customs and traditions. While the Filipinos are not in the home country, certain cultural practices are still observed. This is not surprising since what makes them Filipinos is not really the place, but the customs and traditions they all share. With the respondents having close encounter with the Filipinos, they have attained a definitive understanding of the customs and traditions the former have; removing any perplexity or bizarre conception of such actions.

Cultural practices are shared perceptions of how people routinely behave in a culture (Frese, 2015). These shared perceptions are diverse, yet meaningful. These customs and traditions reveal what is good, true, and beautiful in a given culture. For instance, the Filipino iconic symbols of respect: the "po, opo" and "pagmano" highlight family-centeredness and respect for the elderly which Filipinos value the most. As the respondents mentioned,

"Whenever my children and I visit the

Philippines, relatives there would do 'po' and 'opo' and blessing” (P5)

"My son always says words with po as a sign of respect." (Pl)

"Filipinos respect the elderly so much.

They kiss their hands every time." (P5)

The notion is done whenever Filipinos talk to elders. It came from the Spanish, "mano" which means hand and "po", a word used at the end of every statement whenever addressing elders or superiors to show respect (Abundo, 2015).

Moreover, Filipinos love to give 'pasalubong.' This is a Filipino tradition that has been practiced for centuries. It is a Tagalog word meaning an offering or a present brought by someone for a family or friend (Ethnic Groups Philippines, 2016). As the respondents accentuated.

"I've brought chocolates, coffee, TV, and things like that for my family as influenced by my Filipino friends." (P5)

"When I go out of town, my Filipino workmates would always ask me to buy them something." (P4)

"Whenever I come back here in Qatar, it has been my practice to bring something from home. My Filipino friends ask me for something." (P2)

Aside from the Filipino cultural practices observed by foreigners, Filipinos abide different sets of cultural precepts. These native beliefs range from religion to superstitions. 
The Philippines is a country imbued with varying cultural precepts in the form of religion and superstitions. On one hand, it is said that religiosity is second nature to Filipinos. Even if they are located in a Muslim country like Qatar, they still practice rituals pertaining to their religion dutifully. Non-Filipinos have observed that,

"The first thing I see is that most of them get along with us. Religion is maybe one of the reasons." (P3)

"I am willing to adapt the Filipino's aspect of having respect for people, religion, rules and regulations." (P1)

\section{"The Filipino Culture helped shape me. I became more God-centered and people-Centered." (P5)}

"My Filipino friends always pray before eating. I now pray like them.” (P4)

On the other hand, foreigners have noticed that Filipinos are highly superstitious. They have always believed that there are supernatural forces acting directly upon their lives. Although the world had seen scientific and technological breakthroughs, superstitious beliefs never ceased to exist. And these notions have been recognized by foreign nationals, even acting as mediums for social interaction. As the participants noted,

"My friends always point with their lips

and not with their fingers. This is bad according to them." (P6)

"They believe that during new year, round fruits should be displayed for prosperity." $(P 1)$

"They apply Vicks in everything." (P4)

A discussion of Filipino customs and traditions would not suffice without a conversation on Filipino fashion sense. Without exaggeration, the Filipino has a keen eye towards aesthetics. The way Filipinos dress is actually a reflection of how they are, what they believe in, and what they have been through. In a way, Filipino fashion style has a strong influence on expats. As the participants mentioned,

"I prefer to accept the Filipino culture because it is an impressive culture for me. They are very fascinating in terms of their fashion, cleanliness, maturity honesty and punctuality." (P4)

"Fashion is another commendable thing about the Filipino culture. They dress well, and they know how to dress according to the occasion. And also, Filipinos are very clean and tidy. It is not something that most nations are." (P3)

"There are a lot of things I am fascinated about the Filipino and their culture. If I keep it in hierarchy, the first thing would be their personality. They are very outgoing, friendly, accommodative, and fashion-loving. I am also fashion-loving; therefore, it's one of the main reasons." (P3)

"The Filipinos are very fascinating because they are extremely professional. I can observe their body language, culture, and fashion, also I like their fashion decisions." (P4)

Filipino aesthetic comprises of fascinating pattern designs that capture the eyes of both local and foreign dwellers. Unlike other nationalities, Filipinos dress not so much to impress, but to express their beliefs. Consequently, foreigners are able to adapt this kind of mindset especially to those with Filipinos in their household. Personal appearance is extremely important for Filipinos and great care should be taken to be as well- groomed and smart as possible at all times - whether in a business or social situation event.

\section{"There are three things that I learned from the Filipinos and one of which was the importance of dress code (P3)"}

"I love fashion. The two things that the Filipino culture affected me is the fashion and how to properly deal with people or with a group of people." (P3)

\section{"My Filipino friends are always well-groomed and neat. They dress nice as well. I try to do the same." (P2)}

In a nutshell, the non-Filipinos are able to understand Filipino customs and traditions. Although they may find these bizarre and weird at first, long and constant exposure to these enabled them to understand where Filipinos are coming from. This now paves the way for acculturation and eventually, cultural affinity.

\section{Accuturation}

The process of acculturation does not happen overnight. It is actually a tedious and long process; a by-product of close and contact interaction with others. This close contact with the other has paved the way for cultural exchange and acculturation wherein horizons are broadened and new perspectives are laid out.

Acculturation is a two-way process. It changes the home culture while catalysing change in the foreign culture. In Qatar where different cultures meet, cultures clash, interact, and affect each other. This cultural pluralism is not actually something to fret, but something to rejoice over; an offshoot of multiplicity of perspectives.

Culture is constant. People create cultures and are formed by cultures. It is a primordial to an individual; even a necessity. As such cultural immersion is the main catalyst for cultural acquisition. The non-Filipino expatriates were heavily exposed to Filipino culture, enabling acculturation. As the respondents stated, 
"I learned many things about the Filipino culture. It taught me about friendship and punctuality in work. Most of my co-workers are Filipinos and they are very smart and have good judgments. They also give good ideas and how to minimize or save the expenses in the business." (P4)

"I have become calmer due to my Filipino family and Filipino culture as compared to when I first came to the Middle East wherein I was hot-tempered." (P2)

"I feel comfortable with the Filipino culture having learned it from my wife. I am, sometimes, able to understand their language, Tagalog, which my son also uses. I also use it sometimes when conversing with them which makes me feel part of this culture." (P1)

The present research centres on the journey of foreign nationals as they are exposed and immersed to the Filipino culture. It focuses on their adaptation skills in acculturating a different way of life. Although the respondents admit that culture is nurtured and learned, it is also adapted. This cultural adaptation is not forced upon them, but a by-product of the growing acceptance of the Filipino way of life as an official view of reality.

"I accept the Filipino culture because they are very neat, clean, and educated. I appreciate in what they believe in." (P4)

"I love the Filipino culture. It is very close to my heart." (P3)

"It was very easy for me to adjust in the Filipino culture because I've been friends with Filipinos for almost 15 years. I like their culture and morals more compared to Nepali's because they accept easily." (P4)

Being immersed in a different culture is quite alarming on a foreigner who understands reality differently. Due to certain experiences, it was quite difficult for foreigners to fully accept the Filipino culture. As the respondents stated,

"Sometimes I find the culture weird. I cannot related to some of their practices." (P6)

"There were parts of the culture that were not acceptable at times." (P1)

"Last time I went in the Philippines was December. We killed the pig in the yard and ate it. That kind of shocked me." (P6)

Despite the seeming culture shock encountered, these non-Filipinos have begun to accept and even observe some Filipino ideas and practices which they think would help them understand reality better. From the customs, to its precepts, even to fashion sense, and values, they started to reconcile their own culture with the Filipino culture they are being exposed to.

Adjusting to a foreign culture is dependent on various factors. If the foreign culture is somehow similar to the native culture, then the process of cultural adaptation would be much easier. When an individual's own values overlap with the other culture, it becomes easier to adapt

On the contrary, if the two cultures are contrasting and even hostile to each other, then cultural adaptation would be futile. As the respondents mentioned,
"It was easy adjusting to Filipino culture as my cultures is aligned with it. The cultures are similar. Culture clash would be present if there was difference in values and upbringing and it would be hard to adapt to each other. Adjustment is dependent on upbringing, family setup, and exposure to other cultures." (P2)
"It was not that difficult to adjust because we believe in the same things." (P1)
"For me, I was able to adjust because I have seen some similarities. Although there are things that they do that I do not like, there are still many things that I appreciate about the Filipino culture." (P3)
"I am comfortable as the culture is aligned with my principles, the prospect of family values and respect is present." $(\mathrm{P} 4)$ "My culture is the same with the Filipino culture so it is easy to adjust." (P5)

The Filipino culture has slowly been garnering much more appreciation from foreigners wherein it came to the point of them wanting to live in the Philippines.

"I love the Filipino culture that I want to live there." (P5)

"If given the chance, I might stay there; like vacation or something." (P1)

In summary, Filipino culture has impacted and will continue to impact other cultures through cultural acquisition as long as Filipinos continue to immigrate. Foreigners can view these Filipino traits as either positive or negative which is relative to their own. The point of the matter is that, acculturation is inevitable; enriching both parties involved.

\section{DISCUSSION}

Culture is the way people look at reality. It encompasses religion, food, what people wear, how they wear it, their language, marriage, music, what they believe is right or wrong, how they sit at the table, how they greet visitors, how they behave with loved ones, and a million other things (De Rossi, 2017). It is the characteristics and knowledge of a particular group of people, encompassing their way of life from womb to tomb, from cradle to the grave. No matter what they do, culture is part of the society they live in; whether it is our culture by birth or the culture of the new country in which they reside (Rij, 2017).

People are culture-producing individuals. They have made culture and culture makes them. The production of cultural perspective focuses on the ways in which the content of symbolic elements of culture are significantly shaped by the systems within which they are created, distributed, evaluated, taught, and preserved (Peterson, 1976). 
Without exaggeration, one can surmise that identities are cultural identities. Morality, values, practices, and perceptions are all traits molded by culture, and together these traits create a person's identity. Culture, therefore, can be regarded as the birthplace of the self. To say therefore that one is Filipino is to have a Filipino identity; one who thinks, argues, and speaks like a Filipino.

The Philippines is a country imbued with varying cultural influences. Most of these influences are results of previous colonization, deriving mainly from the culture of Spain and the United States with a sprinkle of oriental flavors. Despite all of these influences, the old indigenous culture and values of Filipinos have never wavered and are clearly seen in their way of life, beliefs and customs. Wherever they go, Filipino culture and values is very evident and has largely been appreciated and even applauded in many parts of the world (El-Saba, 2015).

The rise of overseas workers has made tremendous changes on the concept of culture. There has never been a time in history where exposure to a foreign culture is at its peak. Gone are the days when homogeneity is the norm, but the growing acceptance of different ways of interpreting reality has readily been recognized. Foreign cultural influences have been welcomed with open arms, so to speak.

As of the recent study, approximately 2.3 million of Filipinos are working abroad. Almost $57.1 \%$ of these workers are in Middle East (Philippine Statistics Authority, 2019; Business World, 2018). With the growing number of Filipino expatriates spread throughout the world, particularly in West Asia, the Filipino culture is slowly getting its foothold. It comes to no surprise that more and more people are getting acquainted, even immersed, in the Filipino way of life.

Even though Filipinos are living in a foreign country, Filipino culture is still being practiced. In a way, one can say that it is not the place that makes the culture, but the people. For instance, the Filipino culture is alive and flourishing in Qatar. This small, yet progressive Arabian country has been one of the top work destinations of OFWs ever since oil was discovered in 1939 (Sorkhabi, 2010; Mirasol, 2017). As Filipinos thrive in Qatar, so does the Filipino culture. The process of acculturation then begins. They begin to influence the people they are with, at work, in school, or at home. One can say that foreigners develop a sense of cultural affinity towards what is Filipino because of their continual involvement and immersion with Filipinos and their way of interpreting life.

The Filipino culture is rich and profound. Not only is it imbued with novelty and uniqueness, it has absorbed foreign influences and made them its own. It has become so influential that it has garnered the attention of many foreign expatriates in the course of their stay in Qatar, which is a melting pot of cultures. The data gathered in the results presented shows a significant correlation between how the Filipinos lived to how foreign expatriates in Qatar developed affinity with the Filipino culture. Hence, the Filipinos' way of life directs, guides, and enriches their understanding of reality.
Based on the data gathered from the respondents and the critical analysis of primary and secondary sources, the journey towards cultural affinity starts when the foreign expatriates integrate values; ideals which the Filipinos cherish in their existential context. Then they begin to adapt the Filipinos' customs and practices, even doing the things the former do. And lastly, they begin to understand the deeper nuances of being Filipinos. Acculturation starts and these foreign nationals become more Filipinos in words and deeds.

\section{Filipino Values}

Values are the key building blocks of every cultural orientation (Carpenter \&Dunung, 2012). They are ideals each culture considers to be true, good, and beautiful. They are, for all intents and purposes, what give people their identity as a people, a distinct human society. (Ramos, 2015, 696) They are reinforced notions in each culture that presuppose expected adherence. In such cases that they are renounced, negative remarks or consequences await the defiant.

Values play a vital role in culture. It is by these values that people live by; an avenue where peace and order are maintained in a community. It is the basis of human action and where ideals regarding how people should live are derived. Culture and values are an inseparable set. Both provide the basis for the skills people choose to develop, time choose to invest, and the improvement systems, processes, and habits choose to use (Clemmer, 2015).

It is said that values are impersonal. Although they are important, they are also interdependent ideals which people cannot live without. Values exist without humans, but humans cannot exist without relying on values. To say therefore that there are Filipino values do not, in any way, mean that Filipinos claim exclusive ownership over them. Values are universal and they should remain like that. Therefore, to claim that Filipino values exist is to give testament to the fact that the Filipinos have made their own hierarchy of values; placing on the pedestal those they consider crucial and vice versa. Within any culture is a value system that functions a sense of coherence and a basis for decision making. In every culture, its value system is complex but definitely patterned (rank-ordered). Thus, values have a conventional element in the sense that it sustains, through time, what a culture considers as the way things should be (Ligo-Ralph, 1990).

Although a culture cannot claim exclusive ownership of values, since they are universal, one can never discount the fact that a culture is what it is because of these firmly believed ideals. Each culture gives varying emphasis on them, making a few ideals stand out over the rest. It is possible therefore that they may overlap; similarities may converge.

In the same manner, because of varying emphasis placed, differences in cultural presumptions exist as well. People may perceive differences between and among social groups in the specific behaviors that are seen as exemplars of different values. Thus, by thinking about groups in terms of concrete instances, differences may be stronger than similarities (Hanel et al., 2018). 


\section{From Foreign Migration to Cultural Affinity: The Journey of Foreign Expatriates toward Filipino Cultural Adaptation}

Hence, when we speak of Filipino values, we do not mean that these values are found only in the Philippines (Gorospe, 1974, 43). These values are Filipino precisely because these are what Filipinos consider important in life. Ultimately, this is what they will be known for throughout the world. Not because Americans are not hospitable, or that the Japanese are not happy people, it is just that Filipinos consider hospitality and cheerfulness as their prized ideals. The differences are a matter of the way these values are ranked or emphasized or combined so that they take on a distinctively Filipino slant or cast (Gorospe, 1974, 43).

For instance, hospitality is a commonality in the Filipino character and this is what differentiates the Filipino people and makes them the acclaimed hospitable hosts of Southeast Asia. By far, the hospitality and cheerful disposition of Filipinos are what attract and charm the foreign visitors about the Philippines (Philippine Embassy, Jordan, 2016). In addition, positive values, notably respect for man's dignity and honor, make Filipinos prolific, responsible, and lawful. (Manila Bulletin, 2016).

Values are also learned. They are passed on from one generation to another through socialization. They do not remain stagnant, but changes over time insofar as the progress gained yesterday is the tradition we claim today. And tomorrow's tradition will be what we have managed to advance culturally today (De Mesa, 2003, 22).

Filipino values are instilled early in life. They are enhanced through direct interaction with others, particularly with parents, teachers, relatives, and peers. In sociological parlance, this process is called socialization. It is the incorporation through which human beings become members of particular cultures, learning how to speak as well as how to act and think and feel (Cazden, 2017). It is a process in which members of the society are taught customs and traditions, values, and cultural norms of a certain social group. Through the process of socialization, people take on the beliefs, feelings, and behaviors appropriate to their particular role in their own culture. Much socialization is effected explicitly through language, in the verbal instructions given direct to the society during everyday activities, as well as through practices and aphorisms that express cultural values (Ely \& Gleason, 2017).

Filipino values are part of the identity in which Filipinos are known for. It is a core proponent of the Filipino identity. They are crucial to Filipinos that when their existence is disregarded, one loses the Filipino identity and concept of self, which may invoke social retribution. Losing one's identity involves the loss of the familiar, including language, attitudes, values, social structures and support networks (Bhugra\& Becker, 2005).

Based on the verbal musings of the respondents, the three main Filipino values that the foreign expatriates have adapted are the following: other-orientedness, family-orientedness, and personal integrity. The altruistic nature of Filipinos plays an important role in the development of the non-Filipino expatriates' affinity with the Filipino culture. These values garnered much attention for its inherent "other-centeredness", which the foreigners find appealing. These serve as the pillar of Filipino virtues which are not virtues of an individualistic nature in the same way as most of the cardinal virtues of the Western tradition (i.e. prudence, justice, temperance and fortitude) but are all directed towards the preservation and strengthening of human relationships (Kevin, 2015).

Hospitality, as the main form of other-centeredness, is uniquely Filipino.Thinking of others before oneself is very Filipino. Whether their visitors are Filipino or not, they welcome them with warm hearts and treat them with utmost respect. Filipino families are often more than willing to share not only their meals, but their entire home as well. Filipinos are most expressive of their love and appreciation for people around them by making simple gestures. The Philippines has an exceptional service for foreigners, Filipinos greets everyone they see. They offer to show and tour everyone around and offer you to eat with them (Thomas, 2016).

As a matter of fact, Filipinos would usually greet their visitors with the phrase "Feel at home!" to ensure that they are at ease during their stay. For Filipinos, it is a pleasure and honor to accept foreigners as visitors and build genuine relationships and friendship with them (Ong, 2015). Filipino hospitality and friendliness are said to be one of a kind.

Filipinos are very welcoming and easy to talk to. It is reported from overseas that the Filipino workers' hospitality and friendliness are the two traits that most nationalities adore them for (Sarenas, Pedrajas, \& Belen, 2017). They are willing to offer everything they have just so their guest will feel comfortable. Filipinos are highly praised for their hospitality although, there are times wherein Filipinos go overboard in treating their guests. They either spend too much or prepare too much for their guests. This may have a negative impact on Filipinos, but in the long run, it has contributed to worldwide recognition of this Filipino's most renowned value.

The foreigners, upon the experience of Filipino hospitality, have realized that hospitality indeed goes a long way. Hence, they begin being hospitable as well; welcoming guests with the warmest Filipino-like smile. Filipino hospitality is indeed not something to be swept off the rug, but something to be proud of as Filipinos.

In addition to other-orientedness, the non-Filipino expatriates have understood how important family is for the Filipino. The Filipino family is a very important value in Filipino culture, if not its highest and most pervasive one (Miranda, 1992, 97). The effects of family values can significantly affect one's personality, beliefs, and behaviors which corresponds positively to life experiences (Bartleby, 2017). They have observed that family-orientedness is one of the values that makes the Filipino culture, Filipino.

Family is considered as the foundation of the Filipino society. Filipinos work hard for their family. They even go abroad to work for the sake of the people they love. As observed, they are known to be family-oriented. This is 
actually the reason why foreigners look up to them. Even miles apart from their family, they preserve the relationship through a myriad of ways. The idea of autonomy, self-achievement, and independence so prevalent in the Western cultures sound rather strange to Filipino ears, more use to the phenomenon of intensive mutual interdependence. In fact, an early desire to live independently from family or friends is frowned upon as egoistic and proud attitude. (Tesoro \& Jose, 2004, 194)

Moreover, they do their best to provide for their families, sometimes even their extended family. They treat others the same as their own families, which foreign expats find amazing. If one ends up in the presence of Filipinos for an extended period of time, one can expect the visitor hospitality to turn into genuine familial love (Escalona, 2017). Filipinos get easily attached to anyone when they stay long with them. The family values play a powerful role in shaping these foreign expats through influence and experience.

However, too much emphasis on family-centeredness has its own disadvantages as well. Filipinos are most likely to appeal to 'family' when the going gets tough. For instance, strong family ties can lead to the Padrino system or nepotism. At its most basic, it is having someone in a position of power giving you favors for your endeavors. This usually rears its head when looking for a job or trying to get a position, and getting a government contract. A "Padrino", usually a person of authority within the organization you are dealing with, or someone powerful in a general sense, intercedes on your behalf so you get a favorable outcome. You get the job you wanted (or $a$ job), or the contract is yours (Ramos, 2016).

While there are disadvantages to family-centeredness, it remains a highly prized value for Filipinos and those people they encounter. Albeit the problems, putting family at the center of everything paves the way for harmony and smooth-interpersonal relationships. This may be is the reason why Filipinos are known for their friendliness. Their amiable personality is the product of considering people as members of the family. This is what the foreign expatriates have realized; to consider everyone as family. Familism is embedded in the Filipino social sphere, translating its relational quality outside the family. The Filipinos' strong family values have brought influence in many parts of the world (Morillo et al., 2013).

Moreover, Filipino work ethics is one great factor that the foreign colleagues have appreciated from the Filipino culture. Through creating a positive work atmosphere, foreign expats are able to adapt professionalism from Filipino colleagues. The most overt work ethics among Filipinos is their integrity. This reflects a system in which discourses surrounding workers become fixed in ways that ideologically frame Filipinos as docile and compliant yet industrious and honest (William, 2014).

Filipinos show a strong quality of honesty and good ethics among their colleagues. They have a sturdy sense of personal integrity so to speak. When asked to do a task, they agree to it and do it without hesitation; sometimes even going beyond what was asked. They have a sense of honor and honesty towards any task given to them. Filipinos frequently communicate with their colleagues to gain better understanding. They are transparent, accountable, and fair. Filipinos work through channels than around channels to maintain the integrity of the reporting process (Lagua, 2017). Thus, they exhibit a competitive spirit that is a powerful source of motivation to their colleagues.

On the contrary, Filipinos also display negative work habits. Mañana habit is one of the most negative work traits of some Filipino. It means "mamayana" in Filipino or to do a certain thing at a later time. It simply means finding a way to delay a work to be done (Evans, 2017). This habit shows Filipino culture's lack of sense in time which is most true especially to students and workers (Joaquin, 2014).

While Filipinos tend to procrastinate sometimes, they definitely get the job done. This is the reason why the foreign expatriates have appreciated how Filipinos balance personal and professional life. Strong work ethics and a great sense of duty are just two of the things that an employer can expect from Filipinos. Foreign employers commonly state that the work ethics and dedication of overseas Filipino workers are excellent and unmatched (Editorial Team, 2019).

Other-orientedness, family-orientedness, and personal integrity: values that have been imbibed and ideals that made the foreign expatriates create deep love and appreciation for the Filipino culture. As values are at the heart of culture, their inculcation assure that the Filipino culture has permeated every fabric of their lives. They keep these ideals alive by recognizing their value and importance, (Macasaet, 2013), and by trying to understand why Filipinos have placed them on the pedestal.

\section{Customs and Tradition}

While values remain at the heart of culture, customs and traditions become their concrete manifestation. Customs and traditions are the habitual practices of a culture which stem from the survival routines of ancient societies and civilizations (Beck \&Forstmeier, 2007).

The Filipino way of life is profuse with customs and traditions. It is deeply connected with the history of its people, the experiences wrought, and the legacy carved. It comprises the latent wisdom of the community; the valid confirmation of how to live one's life. They are guides on how to interpret the vicissitudes of experiences one encounters (Gripaldo, 2005).

Like values, customs and traditions are inherited. It is an heirloom that constitutes and protects what it means to be Filipino. It is continuously growing, along with the Filipinos as it is passed on from generation to generation. Although Filipinos are living in a highly globalized era, customs and traditions remain a constant Filipino identity. Albeit some changes, the core of the Filipino psyche remains unscathed by global fluctuations. 


\section{From Foreign Migration to Cultural Affinity: The Journey of Foreign Expatriates toward Filipino Cultural Adaptation}

The three dimensions of Filipino customs and traditions that foreign expatriates have adapted are as follows: cultural precepts, cultural, practices, and fashion trends.

Cultural precepts are beliefs that play a key role in the way a society functions. These are the abstract conceptions that support the societal structure and are a major constituent in the formation of a culture's mores and values.

Filipino cultural precepts range from superstitions to religion. Filipinos are compelled to believe in supernatural phenomena, and omnipotent deities that regulate the way they live their lives (Canceran, D., 2016). One can say that Filipinos are deeply religious; allowing religion, an organization that has always been acknowledged as an influential figure in the social superstructure (Johnstone, 2016; Hunt, 2002) guide their lives.

At the same time, they are also avid fans of superstitions; doing things that might make outsiders scratch their heads. Superstitions are unfounded and irrational beliefs often in the realm of the supernatural. These beliefs are often products of the misinterpretations of phenomena; impulsive hallucinations, or concocted stories made to entertain, or instill fear (Westjohn, Roschk, and Magnusson, 2017; Salazar and Bestard, 2015). They are generally staple in any country found in its mythos, folktales, and paranormal happenings. They have once sought to explain natural phenomena, supernaturally. With the development of science, however, they have been deconstructed. Nevertheless, superstitious belief remain in the collective consciousness of people.

Filipino superstitions have been a huge part of Filipino culture, even before the Spanish colonization. These pamahiin-Filipino for superstition - have always been an integral part of the culture, originating from the pagan beliefs and aggravated by the Chinese traders and Spanish colonizers. For instance, the Chinese have many superstitions of their own, ranging from the zodiac to superstitious beliefs about luck (Faiza, 2018). The Chinese traders brought along a variety of their own superstitions to the Philippines - e.g., Feng Shui, Chinese symbols, wedding practices, etc.- - which became incorporated to the Filipinos' superstitions (Soriano, 2018). The Spanish colonizers used superstition as a form of social control. They spread tales of aswang (monsters), and mangkukulam (witches) to scare people from the countryside and the mountains into moving to the cities, which made the management of the Filipino populace much easier for the Spaniards (Zaide, 2006). During the American colonization, superstition and religion also became a present force as political symbols (Wheatley, 2018).

The foreign expatriates have realized that the Filipino culture is deeply imbued with eccentric superstitions that even a highly-technological society cannot shake. They noticed that these superstitions revolve around major life phases from birth, to birthdays, weddings, and even funerals. These beliefs surrounding major and minor phenomena just goes to show how creative the Filipinos were in interpreting social realities. Even abroad, such superstitions are still widely practiced which made the foreign expatriates appreciate deeper the nuances of the Filipino culture.

Filipinos value religion as an essential part of their life. Even prior to the arrival of foreign religions, the ancient Filipinos have already established a complex religion system that has partial influence over the ancient Filipino society (Castillo, 2015). It is therefore a misnomer to say that the colonizers brought religion, for the ancient Filipinos have already established an intricate system of communion with the divine.

That God exists is a fact for the Filipino. He does not need proofs or arguments for God's existence (Mercado, 1975, 39). Hence, religion became a persisting focal point of the Filipino culture as most Filipinos' lifestyles revolve around it. For instance, a majority of Muslim Filipinos come to pray at mosques 5 times a day. Christian Filipinos often spend their Sundays at church to participate in mass-religious practices. Filipino values, practices, and festivities are heavily influenced by religion; proof to the Filipinos' inclination to reach out to a higher power.

Customs and practices are anchored on Filipino beliefs and values. The development of the Filipino culture is greatly influenced by the concepts brought forth by its beliefs and value system. Christianity, Islam, and the Filipino values determine the Filipino's course of actions. Religious practices such as the fiesta or the devotion to the Black Nazarene continue to be rampant all around the country.

One glaring custom/tradition Filipinos love to do is to celebrate festivities. There are about a hundred different fiestas and festivals celebrated in the country every year. Whenever a good excuse to throw a party and get together with relatives and friends comes up, that opportunity would most likely be seized every time. In the Philippines, no matter how big or small a community is, Filipinos hold a fiesta. Traditionally, the fiesta is a time of joyful celebration for Filipinos, who cook heaps of hearty food, throw open their doors to visitors, and parade in the streets. Some Filipino fiestas have evolved into elaborate, multi-day festivals, while others have kept their community roots (De La Cruz; 2017).

Another example is the deep devotion to the black Nazarene which have attracted people from all walks of life. This historical and iconic statue of Jesus carrying his cross has become an emblem of passion, struggle, and faith for Filipino Catholics. The devotion in Quiapo is somewhat similar to a pilgrimage experience and people do it to pray for spiritual change or purification. Pope Innocent $\mathrm{X}$ also recognized the Philippines' strong devotion to the Black Nazarene of Manila in 1650 (Henden, 2019).

Another example is the Sinulog Festival which is a dance ritual in honor of the miraculous image of the Santo Niño. The name pertains to the strong current movement of the Cebu River which is re-enacted in the dance. Sinulog in Cebu is the biggest festival in the Philippines, celebrating the feast of the Child Jesus, Santo Niño de Cebu, with a dance ritual to the beat of the drums. Held every third Sunday of 
January, it is the largest and most attended fiesta in the country with an all-day-long parade and party (Diaz, 2014).

Aside from these, one of the many notable traditional Filipino practices which have been widely recognized by the foreign expatriates is the use of "po" and "opo" which are said when talking to people of an elderly or higher status (Celero, J. J. O., 2015), and also "pagmano" which is an action done to offer respect (Del Villar, C., 2015). There is also the traditional "pasalubong" which are gifts often offered whenever Filipinos come back home after going somewhere far for long periods of time.

Customs and practices are founded on values and beliefs. Notably, these cultural precepts adapted by foreign expatriates are proofs of the cultural influence that the Filipino values and beliefs hold.

Foreign expatriates have observed precepts turned to practices. They have experienced Filipino religiosity first hand. They have attended many religious festivals, gave gifts during Christmas, and offered a candle for the dearly departed. They have been encouraged to view religion more enthusiastically, to celebrate festivities clothe in the Filipino spirit, and to be wary of spirits who may bring maladies and diseases. They have been encouraged to dance to the beat of the drum during the Sinulog Festival as they have joined thousands of devotees of the child Jesus. They may have understood the reason for the strong attachment of Filipinos to the Black Nazarene.

They have been exposed to cultural eccentrics like doing pagpag after visiting a wake, eating bare-handedly, or pointing at something using the lips. They have come witnessed how young people show respect to the elderly, how weddings and funerals become instant family reunions, and how malevolent beings can ruin the good life. They have experienced these things from their Filipino friends and family and they have become enriched. They have developed cultural affinity. Certainly, the cheerful and celebratory nature of the Filipinos has certainly made a mark on the foreign expatriates.

Aside from beliefs turned into practices, foreign expatriates are inspired/influenced by Filipino fashion trend. The clothes we wear send powerful signals to our peers and strangers, projecting the self-image of us that we want to display (Taylor, 1926).

Fashion has evolved absurdly through time. It is not only about looking good, but a reflection of culture per se. Hence, fashion does not only shed light regarding what the culture considers aesthetically pleasing, it is an extension of the Filipino way of life. Filipino fashion creates a lasting impact on foreigners that attracts them to the Filipino culture. Our taste for fashion defines -not just our individuality, but also our collective cultural identity as one nation (Castro,2019). As culture producing entities, adapting fashion trends is one of the most concrete manifestations of accepting a foreign culture. In a way, non-Filipino expatriates developed cultural affinity by accepting what the Filipinos consider fashionable and in-style. While the Filipino fashion sense has evolved over time, still the Filipinos have a unique set of beauty standards; a combination of indigenous and foreign influences.

Customs and traditions evolve around cultural precepts, practices, and aesthetics. The Filipino culture cannot be what it is without subscribing to its colorful history painted with these cultural fibers. The non-Filipinos were able to immerse themselves in these presuppositions and have come to appreciate them which starts the process of acculturation, paving the way for cultural affinity.

\section{Acculturation}

Being and becoming human in time and space requires specificity. Through such a specific way of feeling, thinking, and behaving, people participate in life; through culture, people live life. (De Mesa, 2003, 13) Hence, culture is an important part of people's identity. It goes without saying that humanity cannot be separated from culture. To praise a culture is to praise the people sharing them. Inversely, to insult a culture is to insult what people believed in.

Culture is an inherent concept that becomes the foundation of any given society. It serves as a unique identity attached to people wherein, they receive recognition for it. Since humanization is only possible through culture (De Mesa, 2003, 14), it has a major role in shaping identity. These identities develop from birth and are shaped by the values and attitudes prevalent at home and the surrounding, noting that the cultural identity, in its essence, relates to our need to belong (Jerbi S., 2014).

Individuals possess a dynamic nature and are in constant interaction with their community. They are the narrators and authors of their own culture. And they express their being and becoming, their dreams and aspirations, their sorrows and triumph, their beliefs and ideals in and through culture.

Cultural immersion starts off the journey towards cultural affinity. It is when a foreigner constantly and frequently interacts with a Filipino gaining much knowledge on the other' values, customs and traditions. This multicultural experience not only provides individuals with opportunities to learn new concepts and knowledge, but often requires the establishment of innovative frameworks, which helps to solve the incongruity when the idea of new learning is incompatible with individuals' prior knowledge structures (Chang et al., 2017).

When faced with a new culture other than their own, people either accept or reject the foreign culture depending on the compatibility of their native culture with that of the former. When people find the culture aligned to their personal beliefs and standards, they tend to accept it more easily than when it is not aligned. We internalize the culture of a particular group. We begin to feel as the community feels, think as the community thinks, value as the community values, and behave as the community behaves. (De Mesa, 2003, 18)

Being open to foreign cultures brings a great deal of benefits. It helps people become more sociable. It also broadens people's perspective on certain topics. However, accepting cultures is not an easy thing to do. Living in a new 


\section{From Foreign Migration to Cultural Affinity: The Journey of Foreign Expatriates toward Filipino Cultural Adaptation}

culture can be jarring and very difficult to process, especially if it is drastically different from your own. A person that is being introduced into a new culture can feel a variety of different sensations (Teasly D., 2015). It requires mentally preparing oneself to adjust to a culture that is unfamiliar. Accepting a culture does not necessarily mean abandoning ones original culture, but merely integrating in one's life and daily routine the practices they have acquired though this might pose a challenge to the person having to shift or balance the practices and beliefs between the two cultures. Bi-cultural people may experience their upbringing as the collision of multiple worlds. They sometimes face criticism for stepping outside the bounds of what's normally acceptable in their heritage culture. (Ketchell M., 2017)

Acculturation is the process of acquiring/absorbing the different aspects of a culture unto one's own culture. It often occurs after exposure, which is its "triggering-factor", wherein a culture has contact with another culture. In this case, cultural acquisition occurs due to the exposure and immersion brought about by working or living in a foreign country. The process of acculturation results in people becoming more alike. As it proceeds, people with different cultural backgrounds will, over time, increasingly share the same attitudes, values, sentiments, interests, outlook, and goals (Cole N., 2018).

Acceptance is the turning point of acculturation, wherein the non-Filipino nationals begin to see points of convergences as their culture and the Filipino culture begin to fuse. This leads to the acceptance and integration of thee Filipino way of life into their view of reality. Central to this adaptation process is the ability of the expats to communicate in accordance to the norms and practices of the Filipino culture and continuous and active engagement in the interpersonal and mass communication activities of the Filipino society (Kim, Y. Y., 2017). Due to the fact that the foreign expats are exposed in a place where Filipino values are observed, they are more likely to adapt and practice the values shown. Acculturation is affected by context (family, work, school, socio-political climate) (Ward, C. \&Geeraert, N., 2016).

Adaptation occurs as the last stage in acculturation wherein a culture inter-fuses with another culture thus completing the journey towards cultural affinity. In this stage, the foreign expat has already adapted the Filipino values, customs, and traditions which is essential in completing the process. It can be drawn out that a person has already formed an allegiance if the Filipino values, customs, and traditions become evident in their lives. Cultural adaptation refers to the process and time it takes a person to acculturate to a new culture; a time wherein the foreign expatriate is both Filipino and native of his/her homeland.

The goal of successful adaptation in the host society is to enable the people to experience a gradual personal identity transformation-a subtle and largely unconscious change that leads to an increasingly intercultural personhood. Of significance in this process is the development of a perceptual and emotional maturity and a deepened understanding of human conditions. Despite, and because of, the many unpredictable vicissitudes of the new life, they are challenged to step into a domain that reaches beyond the original cultural perimeters. Although the old identity can never be completely replaced by a new one, it can be transformed into something that will always contain some of the old and the new side by side, to form a new perspective that allows more openness and acceptance of differences in people, a capacity to participate in the depth of intellectual, aesthetic, and emotional experience of others (Kim Y.Y., 2017).

The journey towards cultural affinity is an intricate and continuous process, a by-product of constant and frequent interaction; a medium of cultural propagation. The process starts off with an encounter with a Filipino. Due to constant interactions with Filipinos, the foreigner becomes exposed to different Filipino precepts and practices. They realize the important parts of the culture, slowly accepting them as part of their lives. This then leads to a gradual adaptation of the Filipino culture which then completes the journey towards cultural affinity.

\section{CONCLUSION}

It has been observed that the Filipino culture has spread in different parts of the world. As the product of its long and colorful history, the Filipino culture has continuously been enriched by its values, traditions, beliefs and practices. It is an amalgamation of foreign and indigenous ideas; a tapestry imbued with different yet complementary threads and designs.

With the advent of globalization, boundaries among nations are drastically diminishing. Crossing boarders has never been as easy and as fast as it is today. This global upheaval encouraged Filipinos to work abroad and try their luck in foreign lands. And with this increase in the number of OFWs comes a greater appreciation of the Filipino cultures' impact in the global arena.

The OFWs easily wove the Filipino culture they learned back home into where they are now. Although, some Filipinos may find it difficult in adjusting in foreign settlements, they never fail to incorporate these valuable practices. They preserve various cultural practices so as to contribute in the community as well as share their culture and values (Zhou, 2016). Due to this, foreign expats were able to recognize the beauty of the Filipino culture wherein they have learned to fuse their own culture and the Filipino culture.

Filipino values have created an impact on the foreign expatriates they encounter. Mainly, Filipino's other-orientedness, family-orientedness, and personal integrity were the values that most respondents have appreciated and have adapted. Other-orientedness is deeply rooted in the Filipino gesture of 'them first before us,' taking care of other people different from them (Sobrepena, 2017). Moreover, they have observed the Filipinos put a high premium on family; something that is true to most cultures. Despite the recognition of differences between immigrants' and Filipino's family values in the literature, they share similarities in factors contributing to family values that lead to family togetherness (Toyokawa, 2013). Moreover, Filipinos are widely known for their great work ethics and an outstanding display of service and performance. They have a great sense of honor and personal integrity towards their work in which foreign expatriates find amazing. Hence, Filipino values have influenced the everyday lives of the respondents as observed from the results. 
Additionally, modeling of customs and traditions become the concrete manifestation towards understanding the Filipino culture. The non-Filipino expatriates have adapted the Filipino cultural precepts which include superstitions and religiosity. They were compelled to believe in supernatural phenomena and omnipotent deities that regulate the way they live their lives (Canceran, D., 2016). Filipino practices like pagmano, po and opo, and diverse festivals in every region have also been observed by non-Filipinos. And the Filipino fashion trends have encouraged them to dress like Filipinos; creating a lasting impact on how foreigners look at beauty insofar as our taste for fashion defines -not just our individuality, but also our collective cultural identity as one nation (Castro, 2019).

Finally, acculturation occurs to conclude the journey; to give it a new direction. This is mainly influenced by a person's exposure and immersion to the culture. It is when they learn and experience the culture first hand insofar as multicultural experiences provide individuals with opportunities to learn new concepts and knowledge, (Chang et al., 2017) enabling them to understand the culture better. This is then followed by the acceptance of the culture, noting the similarities between cultures. The points of convergence will enable them to appreciate more the foreign culture insofar as it is somehow the same. Due to the acquired knowledge and experience, the foreign expats will finally decide to accept the culture and integrate its presumptions into one's own culture. Cultural adaption develops cultural affinity; wherein the local and the foreign marry each other.

The road to cultural affinity is not just a one-way journey. As long as there are OFWs around the world and as long as foreign expatriates are constantly exposed to the Filipino way of life, the expedition becomes a cycle; a never-ending odyssey that could span a lifetime, from here on out. Indeed, the Filipino culture will continue to influence non-Filipinos in more ways than one. Through cultural affinity, Filipinos will rise again as their culture stands on the shoulders of giants. the journey towards Cultural Affinity is marked by three signposts namely: (1) inculcation of Filipino Values the traits and attitudes Filipinos display that heavily influence non-Filipinos; (2) the understanding of Customs and traditions - which discusses the unique traditions Filipinos practice that have consciously or unconsciously impacted the respondents and; (3) Acculturation - which concludes the journey as the non-Filipinos are now able to reconcile their own culture to that of the Filipino culture.

Culture is not only a noun but also a verb (De Mesa, 2003 , 22). The road to cultural affinity is a never-ending process. It is never linear, but cyclical. It is a womb-tomb journey that non-foreigners go through as they maintain a close and intimate or professional relationship with Filipino natives. And as long as these foreign expatriates have close contact with the Filipino culture, they will always discover something new about the former. This journey does not make the foreign expatriates abandon their own native culture, but instill in them deep appreciation and awareness of what is Filipino. They become Filipinos while retaining who they are and what they stand for.

\section{REFERENCES}

[1] Abundo, C. (2015).Filipino Customs and Traditions. Retrieved from https://www.vigattintourism.com/tourism/articles/Filipino-Customs-an d-Traditions?fbclid=IwAR1JCXODRShdmLYA19T2swNKA9pEj6n1 6Mt1rwU6ut21dLgHUAjpx1zm7Vw

[2] Abundo, C. (2015, January 13). Filipino Customs and Traditions. Retrieved from https://www.vigattintourism.com/tourism/articles/Filipino-Customs-an d-Traditions

[3] American Folklore Society. (1906). Journal of American Folklore (pp. 191-204).

[4] Anthony, D. (2016, September 12). Religious Beliefs In The Philippines. $\quad$ Retrieved from https://www.worldatlas.com/articles/religious-beliefs-in-the-philippine s.html?fbclid=IwAR2EcRtS0R24URPGbYM_TtFoh6Kt_mgCehO4q QLk6W0jdTrmW8xkwNyTqE8

[5] Anthony, D. (2019, September 9). Religious Beliefs In The Philippines. $\quad$ Retrieved from https://www.worldatlas.com/articles/religious-beliefs-in-the-philippine s.html

[6] Bernheimer, T., \&Rippin, A. (2013). Muslims: Their Religious Beliefs and Practices. London, England: Routledge.

[7] Bhugra, D., \& Becker, M. A. (2005). Migration, cultural bereavement and cultural identity. World psychiatry: official journal of the World Psychiatric Association (WPA), 4(1), 18-24.

[8] Blumberg, M. (2015, June 26). The Difference Between Culture and $\begin{array}{lll}\text { Values. } & \text { Retrieved }\end{array}$ https://www.onlyonceblog.com/2015/06/the-difference-between-cultu re-and-values

[9] Boyce, M. (2001). Zoroastrians: Their Religious Beliefs and Practices. Retrieved from https://books.google.com

[10] Calderhead, J. (1996). Teachers: Beliefs and knowledge.

[11] Canceran, D. (2016). Interrogating Secularism: The Case of Filipino Experience. Asia Journal of Theology, 30(1).

[12] Carpenter, M. A. \&Dunung, S. P. (2012). This is "What Is Culture, Anyhow? Values, Customs, and Language", section 3.1 from the bookChallenges and Opportunities in International Business (v. 1.0) Retrived from https://2012books.lardbucket.org/books/challenges-and-opportunitiesin-international-business/s07-01-what-is-culture-anyhow-values-.html

[13] Cazden, C. B. (2018). Communicative competence, classroom interaction, and educational equity: the selected works of Courtney B. Cazden. New York, NY: Routledge. Retrieved from https://www.taylorfrancis.com/books/9781315465371/chapters/10.432 4/9781315465371-10

[14] Celero, J. J. O. (2015). Chapter Three “Towards A Shared Future?" Transnational Identity And Belonging Of Japanese-Filipino Families In Japan Jocelyn O. Celero. The Age of Asian Migration: Continuity, Diversity, and Susceptibility Volume 2, 2, 67.

[15] Celero, J. J. O. (2015). Chapter three "Towards a Shared Future" Translational Identity and Belonging of Japanese-Filipino Families in Japan Jocelyn O. Celero. The Age of Asian Migration: Continuity, Diversity, and Susceptibility Volume 2, 2, 67.

[16] Charm, N. (2018, February 12). U. A. E. Dirham. Retrieved from https://www.bworldonline.com/currencies/u-a-e-dirham/

[17] Clemmer, J. (2015). Our Values Shape our Character and Values. Retrieved from https://www.clemmergroup.com/articles/values-shape-character-cultur e/

[18] Del Villar, C. (2015). Correlations between cultural orientations and successful aging of Filipino elders. Journal of Media and Communication Studies, 7(7), 122-144. https://doi.org/10.1111/b.9780631203124.1996.00010.x

[19] Dumaraos, G. (2017, August 30). 11 Things You Should Know About Filipino Culture. Retrieved from https://theculturetrip.com/asia/philippines/articles/11-things-you-shoul d-know-about-the-filipino-culture/?fbclid=IwAR0N3U3Qsfn4J7rusm ctmrc7FZxp5tqE1v43 yBbJJRR7OUo-3zKNXY-LEw

[20] Editorial Team (2019, October 18). Filipino Culture and Values: Work $\begin{array}{lll}\text { Ethic. } & \text { Retrieved }\end{array}$ https://www.sendfriend.io/filipino-values-and-work-ethic-not-your-av erage-employee

[21] El-Saba, A. M. (2018, September 26). The Philippines: Culture and Tradition. $\quad$ Retrieved from https://www.globalizationpartners.com/2015/02/20/the-philippines-cul ture-and-tradition/

[22] Elsevier, B. V. (n.d.). Beliefs about beliefs: Representation and constraining function of wrong beliefs in young children's understanding of deception,13(1), 103-128. Retrieved from 


\section{From Foreign Migration to Cultural Affinity: The Journey of Foreign Expatriates toward Filipino Cultural Adaptation}

https://www.sciencedirect.com/science/article/abs/pii/0010027783900 045

[23] Ely, R. \& Gleason, J. B. (2017). Socialization Across Context, chapter nine from the book The Handbook of Child Language.

[24] Escalona, K. (2017, December 21). 11 Reasons Why You'll Fall in Love With Filipino People. Retrieved from https://theculturetrip.com/asia/philippines/articles/11-reasons-why-yo ull-fall-in-love-with-filipino-people/

[25] Escalona, K. (2017). 9 Superstitions Many Filipinos Still Believe. Retrieved from https://theculturetrip.com

[26] Escalona, K. (2017, August 26). 7 Unusual Filipino Practices Most Foreigners Won't Understand. Retrieved from https://theculturetrip.com/asia/philippines/articles/7-unusual-filipino-p ractices-most-foreigners-wont-understand/?fbclid=IwAR3xzj FpR3c HZGxQc2YrROa4mdUyEMsJ_2IX_y-at4m_3J9vLx1xpHMpsQ

[27] Evans, P. (2018). The manana habit and its effect. Retrieved from https://steemit.com/story/@prince-evans/the-manana-habit-and-its-eff ect

[28] Fallaria, A. J., Jesus, R. D., Carpio, M., Jacinto, F. L., Leon, L. D., Agapito, J., \& Ramos, J. G. (2019). Emerging from the 'worst': An ethnography of the modern Filipino commuting culture behind the Metro Manila traffic crisis. MATEC Web of Conferences, 272, 01032 doi:10.1051/matecconf $/ 201927201032$

[29] Falsetti, S. A., Resick, P. A., \& Davis, J. L. (2003). Changes in religious beliefs following trauma. Journal of Traumatic Stress, 16(4), 391-398. doi: 10.1023/a:1024422220163

[30] Frese, M. (2015). Cultural Practices, Norms, and Values in Journal of Cross-Cultural Psychology, 46(10). doi: DOI: $10.1177 / 0022022115600267$

[31] Gripaldo, R. (2005). Cultural Traditions, the person, and contemporary change: the Filipino experience. In Cultural Traditions and Contemporary Challenges in Southeast Asia: Hindu and Buddhist (pp. 283-307). CRVP.

[32] Hanel, P. H. P., Maio, G. R., Soares, A. K. S., Vione, K. C., Coelho, G L. D. H., Gouveia, V. V., ... Manstead, A. S. R. (2018). Cross-Cultura Differences and Similarities in Human Value Instantiation. Frontiers in Psychology, 9. doi: 10.3389/fpsyg.2018.00849

[33] Hapal, D. K. (2017, June 5). FAST FACTS: How big is the Filipino community in Qatar? Retrieved from https://amp.rappler.com/nation/172058-fast-facts-filipinos-in-qatar?fb clid=IwAR3slLv7KBQ101bDS1sX1Sr9KWSX9CW 3H5dcB0838QH fQt1dgWbN2TFHm0

[34] Heinrich, S. (2017). The 'savage' Filipino natives and their dog-eating habits. Western Illinois Historical Review, Volume 8, pp. 25-35.

[35] Holliday, A. (2018). Understanding intercultural communication: Negotiating a grammar of culture. Routledge.

[36] Igwenagu, C. (2015). Entrepreneurship: An Advocacy For Balancing Gender Inequality

[37] Jerbi, S. (2014). Does culture shape our identity? Retrieved from https://www.wya.net/op-ed/does-culture-shape-our-identity/

[38] Jette, D., Bacon, K., Batty, C., Carlson, M., Ferland, A., Hemingway, R., ... Volk, D. (2003, September 1). Evidence-Based Practice: Beliefs, Attitudes, Knowledge, and Behaviors of Physical Therapists.

[39] Joaquin, H. F. (2014, October 20). Mañana Habit is a Disease.

[40] Kevin. (2015, May 29). Filipino Culture: Getting to know the Filipino People via Filipino Traditions. Retrieved from https://everything-filipino.com/filipino-culture-getting-to-know-the-fil ipino-people-via-filipino-traditions/

[41] Kim Ann Zimmermann. (2017, July 13). What Is Culture? Retrieved from

https://www.livescience.com/21478-what-is-culture-definition-of-cult ure.html

[42] Kim, Y. Y. (2017). Cross-Cultural Adaptation. Oxford Research Encyclopedia of Communication. doi: 10.1093/acrefore/9780190228613.013.21

[43] Kirkpatrick, L. A., \& Shaver, P. R. (1990). Attachment Theory and Religion: Childhood Attachments, Religious Beliefs, and Conversion. Journal for the Scientific Study of Religion, 29(3), 315. doi: $10.2307 / 1386461$

[44] Labrague, L. J., $\quad$ McEnroe-Petitte, D. M., $\quad$ Achaso, R. H. Cachero, G. S., \& Mohammad, M. R. (2016). Filipino Nurses' Spirituality and Provision of Spiritual Nursing Care. Clinical Nursing Research, 25(6), 607-625. doi:10.1177/1054773815590966

[45] Lagua, B. (2017). Integrity in the workplace. Retrieved from https://business.mb.com.ph/2017/04/03/integrity-in-the-workplacel

[46] Ligo-Ralph, V. (1990). Some These Concerning the Filipino Value System. Philippine Quarterly of Culture and Society, 18(3), 149-161. Retrieved January 24, 2020, from www.jstor.org/stable/29792016
[47] Lorenzo, C., Apoloan, J., \&Buenafe, A. (2016, January 1). Locus of Control and Beliefs and Practice of Superstitions in the Philippine Context

[48] Macasaet, P. (2013, October 5). The Importance of Recognizing Our Own Culture. Retrieved from https://nstplupse.wordpress.com/2013/10/05/the-importance-of-recog nizing-our-own-culture/

[49] Manaloto, R. (2014). Perspective from the Philippines. Asian Bioethics Review, 6(4), 409-415. doi:10.1353/asb.2014.0034

[50] Manila Bulletin (2016). Celebrating good, unique Filipino values. Retrieved from https://news.mb.com.ph/2016/11/05/celebrating-good-unique-filipinovalues/

[51] Morillo, H. M., Capuno, J. J., \& Mendoza, A. M. (2013). Views and Values on Family among Filipinos: An Empirical Exploration. Asian Journal of Social Science, 41(1), 5-28. doi: $10.1163 / 15685314-12341278$

[52] Muega, M., Acido, M., \&Lusung-Oyzon, V. (2016). Communication, Social, and Critical Thinking Skills of Students with Low-Power-Distance Teachers in a High-Power-Distance Country. International Journal of Whole Schooling

[53] Ong, K. (2015). Hospitality- A Trademark of Filipinos. Retrieved from https://www.wya.net/op-ed/hospitality-a-trademark-of-filipinos/

[54] Philippine Statistics Authority. (2019). Total Number of OFWs Estimated at 2.3 Million

[55] Religious beliefs and practices among 52 psychiatric inpatients in Minnesota. (1989). American Journal of Psychiatry, 146(1), 67-72. doi: 10.1176/ajp.146.1.67

[56] Resto, J. (2017). Filipino superstitions. Retrieved from https://www.kuyaj.ph

[57] Retrieved from https://ayajoaquin09.wordpress.com/2014/10/20/manana-habit-is-a-di sease/

[58] Saba, A. (2018, September 26). The Philippines: Culture and Tradition. Retrieved from https://www El.globalizationpartners.com/2015/02/20/the-philippines-culture-and-t radition/

[59] San Juan, E. (2019). From Exile To Diaspora. Retrieved from https://books.google.com

[60] Sapitula, M., \& Cornelio, J. (2014). FOREWORD TO THE SPECIAL ISSUE: A Religious Society? Advancing the Sociology of Religion in the Philippines. Philippine Sociological Review, 62, 1-9. Retrieved January 26, 2020, from www.jstor.org/stable/43486490

[61] Siojo, R. (2017). The Philippines - Superstitions and Beliefs. Retrieved from https://fitness-gear-equipment.knoji.com/the-philippines-superstitionsand-beliefs $/$

[62] Sobrepena, R. (2017). Why Do Foreigners Love The Philippines? Retrieved from https://oasisregency.com/foreigners-love-philippines/

[63] Tampos-Cabazares, S., \&Cabazares, J. (2016). 'Kultura' in the 21st Century Filipino Language: Revisiting the Western Critique of 'Culture'.

[64] Thomas, A. (2016). Filipino Hospitality: A Trait We Can All Take Pride In. Retrieved from https://balay.ph/filipino-hospitality-culture/

[65] Toyokawa, N., \&Toyokawa, T.(2013). The construct invariance of family values in Asian and Hispanic immigrant adolescents: An exploratory study. Asian American Journal of Psychology, Vol 4(2), 116-125. doi: 10.1037/a0029170

[66] Tsai, L. C., \&Seballos-Llena, I. F. (2019). Reflections on Adapting Motivational Interviewing to the Filipino Cultural Context. Retrieved from

https://www.researchgate.net/profile/Laura_Tsai/publication/3334891 28 Reflections on Adapting Motivational Interviewing to the Fili pino Cultural Context/links/5cf037ef299bf1fb184b9350/Reflectionson-Adapting-Motivational-Interviewing-to-the-Filipino-Cultural-Cont ext.pdf

[67] Wickberg, E. (1962). Pacific affairs.

[68] Wimmer, H. (1983). Beliefs about beliefs: Representation and constraining function of wrong beliefs in young childrens understanding of deception. Cognition, 13(1), 103-128. doi 10.1016/0010-0277(83)90004-5

[69] Zhou, M. (2016). Contemporary Asian America (third Edition): a Multidisciplinary Reader. New York University Press. 